\title{
J.W. Davidson and W.K. Hancock: Patronage, Preferment, Privilege
}

DOUG MUNRO

Victoria University of Wellington

There was a broad, but by no means complete, consensus among the contributors to The Oxford History of the British Empire that W.K. (Sir Keith) Hancock (1898-1988) 'was far and away the greatest historian of the Empire and Commonwealth'. ${ }^{1}$ An Australian Rhodes Scholar and an 'All Souls man', Hancock wrote and edited some 20 books, depending on how they are counted, including an iconoclastic short history of Australia (1930), the magisterial Survey of British Commonwealth Affairs (1939-1942) and the two volume biography of J.C. Smuts $(1962,1968)$. He held chairs at Adelaide (taking up the appointment at the age of 28), Birmingham, Oxford and London, as well as overseeing Britain's World War II 'Civil Histories'. His final tour of duty at the Australian National University (ANU) in Canberra capped off a distinguished career and enabled Hancock's country and calling finally to converge. He was 'the greatest historian Australia has yet produced'. ${ }^{2}$

One of Hancock's Canberra colleagues was the New Zealander J.W. (Jim) Davidson (1915-1973), the Professor of Pacific History within the Research School of Pacific Studies. Davidson was notable for his role as constitutional adviser to a succession of Pacific Island territories in the throes of decolonization, beginning with Western Samoa in 1959 and followed by the Cook Islands, Nauru, Micronesia and Papua New Guinea. His book on the emergence of the modern Samoan state (Samoa mo Samoa) was his

\footnotetext{
Grateful thanks are extended to the Masters, Fellows and Scholars of St John's College, Cambridge, for permission to quote from Hancock's report, and especially to Malcolm Underwood, the College Archivist, for his considerable assistance. G.A. Wood and Tim Beaglehole also allowed quotation rights to material under their authority. My work on Davidson has been assisted by the award of a Harold White Fellowship at the National Library of Australia, and a grant from the Ministry of Foreign Affairs and Trade. Earlier versions of this paper received the benefit of comments from Robert Dare, J.H. Davidson (who is writing a biography of W.K. Hancock), Niel Gunson, Anthony Low, W. David McIntyre, Ann Moyal and Jane Samson. The two anonymous readers for this journal were most helpful in clarifying issues and in sorting out last minute problems.
} 
magnum opus and an articulation of his credo as the participant historian who 'made' as well as recorded history. ${ }^{3}$ His earlier work was seminal. He did for the Pacific what others did for African and Southeast Asian historiography in turning conventional imperial history on its head and shifting the focus from European activity to Islander response. He went on to found an 'island-oriented' school of Pacific Islands history that focused on culture contacts: he insisted on research into and an understanding of the Island societies in which European activities were played out and where events were enacted. ${ }^{4}$ Nevertheless, Davidson is today probably more highly regarded by historians of empire, whose subject he tried to undermine, than by the generality of Pacific historians whose specialization he helped to define. In the historiographic chapter in The Cambridge History of the Pacific Islanders, Davidson gets a cursory mention for 'mentor[ing] the reorientation of Pacific history' and for his involvement in the decolonization of Oceania. ${ }^{5}$ By contrast, he is considered at greater length in the historiographic volume of The Oxford History of the British Empire, and more recently has been hailed by Ronald Hyam for his pivotal role in the establishment of the 'Expansion of Europe' course at Cambridge University. ${ }^{6}$

The relationship between Davidson and Hancock extended almost 30 years. Their paths converged, diverged and intersected again, beginning in the early 1940s when Davidson had just completed the doctoral thesis that would alter the mental map of Pacific Islands historiography. It was a changing relationship, and an unequal one, as relationships are wont to be, with Hancock initially a warm supporter of 'this admirable young man'. But initial approval gave way to disenchantment and it nearly ended in tears as the young paragon transformed, in Hancock's mind, to a middle-aged disappointment who had wasted his opportunities. This essay, which focuses on the Davidson side of the story without necessarily taking Davidson's point of view, is intended as more than a commentary on the unpleasantries of academic life. Rather, the two men's relationship raises questions about the connections between academic patronage, institution building and personal interaction that are part and parcel of professional opportunity, career advancement and scholarly output within the privileged environs of Oxbridge and the Australian National University.

\section{Academic Background}

As a schoolboy, Davidson took out several class prizes but his undergraduate record at Victoria University College in the mid-1930s was solid rather than distinguished. He did not achieve any 'A' grades for his undergraduate courses. But Davidson's work steadily improved, culminating in the award of the University Senior Scholarship in History for attaining the highest 
marks in the third-year examination. ${ }^{7}$ He was awarded the Jacob Joseph Scholarship for his Honours year and received a First Class for a thesis on Scandinavian settlement in New Zealand. In the view of his thesis supervisor, J.C. Beaglehole:

Mr. Davidson is a man of uncommon ability, and as a student of history displayed not only capacity for hard work and solid reading but also perception, originality, and subtlety of mind well above the average. He was at his best as a thesis writer, and his study of the Scandinavians in New Zealand is an exceedingly good piece of work in a rather difficult field. Mr. Davidson has an unusual grip on the problems and methods of research - he is careful and thorough, with the beginnings of a sound technical equipment; he has a sense of style, a sense of proportion, and a sense of humour. ${ }^{8}$

The (anonymous) British examiner was less effusive: 'I shall mark it A-. There are distinct elements of first class work and this will help towards a first, but it does not exactly demand one. ${ }^{9}$ In any other year, Davidson might well have secured one of the two coveted scholarships to Oxford that were set aside for New Zealanders. But in 1938, he was up against an unknown history student from Canterbury University College, Neville Phillips, whose consistently higher overall grades caused an upset. To say that Davidson was shaken at this unexpected defeat is not to exaggerate - although he and Phillips got on when they travelled to Britain on the same ship. ${ }^{10}$ Unable to get into Oxford, Davidson had to settle for Cambridge with the award of a Strathcona Scholarship and a place as a Research Student at St John's College. Three-and-a-half years later, in May 1942, he presented his PhD thesis, 'European Penetration in the South Pacific'. ${ }^{11}$

The thesis was examined by E.A. Benians and A.P. Newton, two of the three joint editors of The Cambridge History of the British Empire, who had few criticisms. ${ }^{12}$ On substantive matters, Benians might have been expected to provide the more informed comments since he had written the chapter on the Pacific Islands for The Cambridge History of the British Empire - but only in the absence of anyone else being willing or qualified to do so. ${ }^{13}$ Yet Newton is the more perceptive. He recognized, first, that Davidson was attempting to write in an informed way on Pacific Islanders and trying to place events within an indigenous framework; and, second, Davidson demonstrated the interconnectedness of European commercial and missionary activity and how this precipitated action from the imperial centre, ultimately leading to annexation in both New Zealand and Tahiti. The periphery, in other words, took explanatory precedence over the centre. ${ }^{14}$ These conceptual advances owed little, if anything, to Davidson's thesis supervisor, Eric Walker, a conventional historian of Empire - although 
Walker was very helpful in suggesting African comparisons and later in opening the door of opportunity. ${ }^{15}$ Rather, Davidson was encouraged in his thinking by the anthropologist Raymond Firth, a fellow New Zealander and Professor of Anthropology at the London School of Economics, with whom he developed an abiding friendship. ${ }^{16}$

Conditions of war held up the careers of many budding historians, an example being Neville Phillips who went to the front. For others, the war created opportunities. ${ }^{17}$ Davidson had already been engaged by Marjory Perham's 'Studies in Colonial Legislatures' project, based at Nuffield College, Oxford, to write the Northern Rhodesia volume. ${ }^{18}$ Perham wished to keep Davidson in her stable, but just before she could obtain the necessary funding, Davidson was offered a job with the Naval Intelligence Division (based at the Scott Polar Institute at Cambridge) to assist Firth in producing the so-called 'Admiralty Handbooks' relating to the Pacific Islands. ${ }^{19}$ Explicitly part of the war effort, the Handbooks in their entirety covered most parts of the globe and were intended to produce precise information for British troops fighting overseas. Davidson thus remained wedded to the Pacific. Nonetheless, it is an interesting speculation where his career might have headed had he been secured by Perham and diverted into African history.

\section{Hancock's Entry}

The younger Davidson's reputation with his peers was put to a sterner test when he applied in 1943 (unsuccessfully) and again in 1944 (successfully) for election to a research Fellowship at St John's College. The procedure was for the candidate to present samples of written work, with accompanying commentary, while the College in question would solicit reports on the candidate's suitability. Davidson presented his MA and $\mathrm{PhD}$ theses and furnished a self-assessment of their scope, methodology and significance. The assessors, for their part, were specifically asked whether the candidate's work could be regarded as an original investigation, and whether it indicated future potential. In 1943, the College solicited reports from G.N. Clark (1890-1979), the newly appointed Regius Professor of Modern History at Cambridge, and W.K. Hancock. ${ }^{20}$ The curious feature of Clark's report is the rapid alternation of praise and criticism with each point often cancelling out the one before. Clark's assertion that Davidson 'seems in places overcautious' is ironic given that Clark was notably just that, whereas Davidson was highly intuitive, quite prepared to take risks, going so far as to say that facets of New Zealand history were more accurately conveyed by novels, such as William Satchell's The Greenstone Door (1914) and Jane Mander's The Story of a New Zealand River (1920), than by historical research. ${ }^{21}$ Clark's muted enthusiasm and reluctance to chance his arm on Davidson's 
potential is in character because Clark 'was not the person to stick his neck out either for causes or persons'. ${ }^{22}$ While not exactly being non-committal, a fear of flying and a tendency to hedge his bets is palpable; and he fits the description that Davidson gave a year before that 'Too many professors won't take the risk of saying what they think and become so guarded in their statements that they make no impression at all'. ${ }^{23}$

There was no holding back with Hancock. His report on Davidson is assertive and unequivocal, and it stands out from the others in matter and manner. Addressed to the Master of St John's in letter form, it is reproduced here in part:

To begin with the smaller and earlier dissertation on the Scandinavian settlers. In scope and length it resembles the majority of dissertations submitted by New Zealand candidates for the degree of M.A. in History. I examined for the University of New Zealand from 1935 to 1937, and in each of my three years as examiner I read on the average about a dozen of these dissertations. There were always one or two with some alpha quality. I am quite certain that I would have given Davidson's dissertation an alpha mark if it had come to me as an examiner. ${ }^{24}$ Whether or not I should have found it outstanding among the five or six really good theses of my three-year period I can't at this distance of time say. Certainly it would not have been the only one composed with an intelligent use of source material and with the added quality of enthusiasm and sympathy which one expects to find in the work of a 20- or 21-year old student. But I think I should probably have given Davidson some extra credit for getting away from papers and books and exploring his Seventy Mile Bush and talking to the people there. This helped him to bring his subject to life. It was an added indication that he possesses qualities of resourcefulness and imagination promising well for his future performance in historical research. ${ }^{25}$

Hancock was bound to be impressed with this aspect of Davidson's work. Like G.M. Trevelyan before him, Hancock had tramped the Italian countryside as part of the research for his first book on an aspect of the Risorgimento. ${ }^{26} \mathrm{He}$ then went on to say:

In his later and longer dissertation he has, I think, amply fulfilled that promise. Indeed, I would go further than that. The earlier dissertation shows soundness in method and imaginative understanding, but that later one has also some other very impressive qualities. In particular it has the quality which I call span. Many of the episodes and events with which Davidson deals are in themselves trifling, but he makes them significant by bringing out their relations and wider implications. Even when he is discussing trivial exports from Sydney, or the obscure 
adventures of Peter Dillon, he is all the time handling very important themes. By studying European civilisation on its advancing fringes, he is telling us a very great deal about its nature in this period - sometimes in other periods too, for he has a quick eye for comparisons and analogies, and in my opinion does not overstrain them, at least not often. I give him praise for understanding so well the inter-relation of those aspects of European expansion which have so often been treated separately or related to each other by crude over-simplification: I am thinking in particular of the commercial, missionary and governmental activities. His method in probing these relationships is, I think, exemplary, a combination of detailed research into particular events and thought about general principles. For example, he is quite right to support his studies of the Residency and the fictional sovereignty of the United Tribes by the appendix on Admiralty Criminal Jurisdiction. Here and elsewhere he sees how the practical problems which his Pacific Ocean adventurers were facing in this period were in part determined by the theories which London officials or lawyers held in the same period. This awareness strengthens his study of the jurisdictional problems. A similar awareness strengthens his study of the commercial and religious problems, and indeed of the whole complex of which religion, commerce and jurisdiction were facets.

Hancock's notion of 'span' is critical to this part of his assessment. In a celebrated passage, he said that Mary Kingsley (1862-1900), the English explorer and advocate in West Africa, 'possessed the three cardinal virtues which distinguish the great historian from the crowd of journeymen. These virtues are attachment, justice and span'. ${ }^{27}$ 'Attachment', said Hancock, is to the particular things while 'span' involves a consciousness of the relationship of these things. Hancock's praise for Davidson is a clear case of concealed autobiography, because Davidson's analysis possesses the virtue of span in that it makes the necessary connections. This is precisely what Hancock attempted in his Survey of British Commonwealth Affairs.

Briefly, Davidson argued that the quickening pace of missionary, trading and whaling activity had political repercussions. He did not simply detail the phases and processes of missionary and commercial activity, such as the pork trade in Tahiti and the flax trade in New Zealand, but drew out their wider interrelationships and implications - namely that the growing European presence led to permanent settlement and exacerbated problems of law and order which local authorities found beyond their means of control. Britain, the dominant power in the Pacific, opted for a variety of counter measures, including a policy of support to established native governments that were organized along recognisably western lines. In Tahiti, a centralized kingdom 
under the Pomare dynasty floundered, despite a missionary-inspired Code of Laws, because it could not control the growing European element, and a French protectorate was declared in 1842. The 'fiction' of native sovereignty was nowhere more apparent than in New Zealand where the structure of Maori society precluded the formation of a centralized Polynesian kingdom, and again the eventual solution was annexation.

'European Penetration' was actually more concerned with New Zealand than the oceanic Pacific Islands, and Davidson felt the New Zealand sections were the best parts of his thesis. He was particularly concerned to demonstrate that the eventual annexation of New Zealand was only marginally prompted by pressure from E.G. Wakefield's New Zealand Association-cum-Company and its plans for systematic colonization. That was the prevailing interpretation. ${ }^{28}$ To the contrary, Davidson argued, the origins of annexation related primarily to the deteriorating situation brought about by unofficial European activities, mostly emanating from New South Wales: 'the movements [and activities] of the settlers were ... the determinants of imperial growth'. ${ }^{29}$ This interpretation owed some of its impetus to C.R. Fay's notion of 'informal empire', enunciated a few years earlier. ${ }^{30}$ Nevertheless, it was a thoroughgoing revision in respect of New Zealand and Pacific history which Hancock (and the thesis examiners for that matter) did not seem to notice. W.P. Morrell had argued broadly along these lines in 1935, giving weight to the growing tempo of European activity and the disorder it created, but he placed some emphasis on New Zealand Company pressure contributing to the decision to annex. ${ }^{31}$ As Morrell himself said to Davidson, 'I must say in regard to New Zealand in particular, where so much work has already been done, that I was much struck by the freshness of your approach and the results that it yielded'. ${ }^{32}$

However, Hancock did recognize, as had Newton, Davidson's contribution to culture contact studies:

His treatment of Polynesian society has similar merits. I should like to know how Dr Firth appraises this part of his work. It may be that his anthropological knowledge is too skimpy; he may have made mistakes of method and judgement. But I believe his approach is right. I feel sure that he has asked the right questions. If, in addition, he has given the right answers - e.g. with regard to Tahiti - they will deserve a great deal of attention. Quite a lot of people nowadays are studying 'culture contacts' between advanced and primitive peoples; but not many have so defined this subject as to combine a close study of local detail with awareness of a complicated and far-extending background both on the side of the advanced culture and on the side of the primitive: one side or the other is usually neglected. 
. . . But now I shall say something to temper all this praise. It may be that Davidson's eagerness sometimes makes him squeeze more out of his sources than they really yield, or at any rate more than ought to be drawn from them until other sources have been examined. I should expect that there is a good deal of additional material to be examined in the P[ublic] R[ecord] O[ffice] - I don't mean that Davidson need painfully tread the well-beaten path of political record, but on his chosen subjects there must be a good deal of evidence in the Admiralty papers and elsewhere. However, this admirable young man has forestalled this criticism by a reference in his preface to war conditions and a confession that much research remains to be done, not only in the P.R.O. but in continental archives.

Wartime conditions certainly inhibited Davidson's research, as they had Morrell's. Relevant documentary series from the PRO were dispersed to various country houses for the duration to lessen their chances of being bombed out, various repositories had early closing hours as a blackout precaution, and on several occasions Davidson's research was interrupted by air-raid sirens and he was bustled away to a bomb shelter. Davidson, moreover, deliberately avoided the manuscript records of the London Missionary Society. Having good grounds to fear vetting of his work in return for access, he satisfied himself with the Society's published Transactions. ${ }^{33}$

Finally, Hancock provided a prescription for Davidson's next three years of work:

1 A wide and persistent reading, not only in Colonial History, but in modern European History, and in addition some other discipline taken very seriously, international law, perhaps or anthropology.

2 The preparation of one very severe article for the E[conomic] H[istory] $\mathrm{R}$ [eview] to give him a through gruelling in the fatigue of meticulous documentary research. ${ }^{34}$

3 Four or five hours of teaching a week. And of course I should mix all this up with a bit of travel to places connected with his studies and interests, because I should be most anxious for him not to forget the lesson he learned in the Seventy Mile Bush.

4 After all this, I should feel certain that he would become an unusually distinguished scholar and - if he has the other gifts, and his style suggests that he has them - a stimulating and brilliant teacher.

With such glowing endorsement, it is a cause for wonderment that Davidson was initially unsuccessful at securing election to a Fellowship at St John's College. The disappointment gnawed at him for months. Soliciting reports 
from historians of such distinction as Clark and Hancock shows that the College took the exercise seriously, but why their favourable recommendation in Davidson's favour was ignored is not readily apparent. The following year, on the basis of rather skimpy reports from Walker and Firth, Davidson was elected to a Fellowship at St John's College, and the year after was appointed University Lecturer in Colonial Studies. The firepower that Davidson was able to command in the choice of referees is testament to his growing reputation; in addition to Firth, Perham, Benians and Walker was the geographer Clifford Darby, his former colleague at the Naval Intelligence Division. ${ }^{35}$

\section{A Continuing Association}

What stands out about Hancock's report, in contrast to Clark's, is a willingness to back himself and recommend so strongly a candidate he hardly knew. Hancock's three-year prescription for 'this admirable young man' is characteristic of Hancock's hands-on approach and readiness to give direction. It would have been to Davidson's advantage had Hancock's recommendations been followed, especially in the matter of 'a thorough gruelling in the fatigue of meticulous documentary research'. The loss is a telling one because Davidson never overcame the aversion to sustained archival research that, ultimately, prevented the publication of his $\mathrm{PhD}$ thesis.

Hancock's 'great interest' in Davidson's work was reinforced by his wife Theaden being a talks producer on the BBC's Overseas Service with responsibility for Pacific Islands affairs. ${ }^{36}$ She had asked Davidson if he was interested in preparing some talks for broadcasting, which he was. As Davidson said in a letter to his mother:

Mrs Hancock says that her husband suggested me \& I know that Firth has also done so .... Incidentally, the letter from Mrs Hancock confirmed what I had suspected - that St John's had sent my thesis to Prof. Hancock for his opinion of it; I now find, too, that he has just recently discussed it with Firth \& that his opinion was very favourable ... I am glad it went to Hancock, for though he was not likely to express himself in terms of violent praise, there is no one for whose opinion I would have a higher regard. He has a far keener mind than the vast majority of historians \& is certainly amongst the most brilliant half-dozen historians in the country. So I hope very much that I may some time get from him his views of my thesis - what he found least convincing as well as what he most approved. ${ }^{37}$

As this letter indicates, Hancock and Davidson were already known to each other, having met on an (unspecified) previous occasion. Davidson 
at this time was at the Naval Intelligence Division. Hancock for his part was Supervisor of the [British] Civil Histories of World War II. ${ }^{38}$ In June 1944, Davidson and Hancock's paths crossed again when Firth suggested that Davidson become involved in the 'Civil Histories' project, in addition to his duties with the Naval Intelligence Division. Arrangements were made that he collaborate with Sir John Shuckberg but it became evident that Davidson was overcommitted. He not only had a strenuous job with the Naval Intelligence Division but was also trying to finish a book on the Northern Rhodesian Legislative Council, and he pulled out of the 'Civil Histories' project in October. There were no hard feelings.

Davidson and Hancock had few, if any, dealings for another four years, until Firth recommended Davidson (age 32) for the chair of Pacific History at the newly-established Australian National University. ${ }^{39}$ Both were Academic Advisers to the nascent institution along with Howard Florey for the medical sciences and Mark Oliphant for the physical sciences. Firth was the instigator but with the full endorsement of Hancock, who was prepared to back his initial judgement of 'this admirable young man'. Here, the force of patronage comes into play. Davidson was seen as having the double advantage of academic respectability and first-hand experience in contemporary Pacific affairs, having had two tours of duty in Western Samoa as advisor to the New Zealand government, with Firth commending him to ANU as 'a first class scholar of meticulous accuracy and a cultured man with a wide range of interests' ${ }^{40}$ Firth was also aware that Davidson was runner up, ahead of several more experienced candidates, for the Beit Professorship of the History of the British Empire at Oxford. ${ }^{41}$ Academically, however, the ANU recommendation was based largely on perceived promise, and an exception to Hancock's preference for 'proven men of middle age', ${ }^{42}$

\section{At Canberra}

Davidson took up his Canberra appointment in December 1950 but cracks were starting to appear in the relationship. The previous year, Hancock had presented ANU with the virtual ultimatum that he be appointed Director of both the nascent social science schools (the Research School of Social Sciences, which was always his for the taking, and the Research School of Pacific Studies). The University Council declined his demand and he severed his connection with ANU. Davidson unwittingly got caught up in the dispute when Hancock attempted to use Davidson's appointment to bolster his own position: 'on the Pacific Studies side, I have the written assurance of Mr. J. Davidson, the "Pacific Historian" mentioned in Professor Firth's memorandum, that he will go with me to Canberra. Mr. Davidson adds that, Professor Firth having withdrawn, he will go with me but with 
nobody except me. I did not invite this statement and I do not welcome it; but it is one of the hard facts that I am bound to report to Council'. ${ }^{43}$ In all probability, Hancock put the words into Davidson's mouth in order to shore up his position vis-à-vis the University Council. His efforts to recruit first-rate 'chaps' to ANU were done in an excessively personal style ('will you come if I do?') that disconcerted several members of the Council. It was, as the official ANU historians explain, 'a bad tactic ... And the veiled threat was undermined when Davidson ... said nothing [to ANU] about coming only if Hancock were appointed director' ${ }^{44}$ Hancock then resigned as one of ANU's four External Advisors with considerable ill grace - one of those drastic actions that made Hancock, from time to time, a distressing colleague. He harboured an unreasonable grudge and a few years later gave a misleading account of events in his autobiographical Country and Calling. ${ }^{45}$ There probably were hard feelings towards Davidson on this occasion.

Davidson intended to remain in Canberra for about five years and move on to a chair at Oxford or Cambridge, but an indifferent publishing record during the 1950s prevented his return to Oxbridge. ${ }^{46}$ 'European Penetration' remained unpublished. He commenced the necessary revisions once he got to Canberra but was deterred when his departmental colleague Ethel Drus warned that the eventual book would be pilloried unless he immersed himself in the records unavailable to him in wartime England. ${ }^{47}$ Both Walker and Hancock had stressed the need for this follow-up research. ${ }^{48}$ Part of the problem, besides Davidson's dislike of documentary research, was that the Australian Joint Copying Project was in its infancy and many of the required records were not yet available in Canberra on microfilm. Probably, though, Davidson too readily allowed himself to be talked out of the thesis revision. He did publish an important revision article containing the gist of his reinterpretation of the annexation of New Zealand, but the abandonment of the thesis rewrite was a severe loss to Pacific Islands historiography. ${ }^{49}$ As a substitute, he continued working on his biography of the trader-adventurer Peter Dillon, whom he had discovered during his thesis research. $\mathrm{He}$ spent his 1956 study leave researching Dillon but the biography had to be posthumously published..$^{50}$ There were other casualties along the way: he never made a start on his promised short history of the Pacific Islands ${ }^{51}$ an edited collection for the Hakluyt Society on the scientific aspects of Captain Cook's voyages floundered, ${ }^{52}$ and his published articles on the contemporary Pacific were never brought together as a book, as he intended..$^{53}$ Davidson was probably overrating himself when, in 1956, he remarked that the vacated Rhodes Professorship of Imperial History at London was 'a post I might have got myself had I been willing to apply'. ${ }^{54}$ 
Several reasons can be suggested for Davidson's literary constipation. His perfectionism had an inhibiting effect and he was disinclined to publish for the sake of publishing; his willingness for committee work may itself have been a subconscious substitute for research and writing; he was too sociable for his own good; and the rigours of 1950s Canberra encouraged frequent weekend visits to Sydney and to the southern New South Wales coast. Being the only unmarried professor at ANU, moreover, had a paradoxical effect; although freed of family responsibilities, he was at a loose end during evenings and fell prey to the 'continuous round of diplomatic cocktail parties in Canberra, and of course Jim was a favourite guest for dinner parties to look after the odd woman who was without an escort'. ${ }^{55}$ But these extenuating circumstances would not have prevented a Hancock or a Morrell from getting on with their writing: "there are intellectual and, if you like, personality traits that have to be built into the explanation . . ., ${ }^{56}$ and in Davidson's case there is a correlation between compulsion and productivity. When pressed with invitations and confronted by external deadlines, he was productive, otherwise not. In short, Davidson's body of published work since his arrival at ANU was meagre and there was no big book in sight.

Retribution was afoot. Hancock was inveigled back to ANU in 1957 as Director of the Research School of Social Sciences and Professor of History. Conditions were different: his former adversaries were no longer there, and he welcomed the challenge of his broad brief to bring to order the 'rabble' of individualists who occupied the two social science schools. ${ }^{57}$ Upon arriving, he was shocked that a number of senior academics, among them Davidson, had published so little. Hancock, who 'had the spirit of the puritan without probably at that time believing in God', ${ }^{58}$ did not suffer 'evaders' gladly, and he felt badly let down that Davidson had fallen short of expectations and not vindicated his patronage. It is worth recalling that Hancock had expressed confidence, when recommending Davidson for a Cambridge Fellowship, that 'this admirable young man' would become 'an unusually distinguished scholar'. The point here is that Hancock was insistent - and in contradistinction to the more leisurely Oxbridge tradition - that publications be the main criterion of academic achievement. The academic culture at Oxbridge was that one published only when one had something to say. Davidson had plenty to say and was expected to do so by ANU, where greater emphasis was placed on what is now termed 'productivity'. The continued patronage that Hancock assumed over Davidson was not out of character. Hancock was neither arbitrary nor capricious in dispensing patronage - unlike, say, the French historian Fernand Braudel, of the Annales school, 'an oppressive and manipulative mentor' who played favourites, took lasting dislikes and dictated the choice of research topics. ${ }^{59}$ 
Nonetheless, Hancock's inclination to give direction and expect favours could be presumptuous, and Keith Sinclair recalls that Hancock was a charming, yet very demanding, prima donna: 'He could exploit other people ruthlessly', said Sinclair. 'He asked me whether I would do some research for him, which would have meant abandoning my own research for a month or more. I only had a year in the United Kingdom [on study leave] so I refused, to his great annoyance. ${ }^{60}$ In short, he expected those beholden to him to do his bidding and came down heavily on protégés (his 'boys') who fell out of favour.

All the same, Hancock's views about the responsibilities that attached to the privilege of being an ANU professor had salience in the context of resentment from other Australian universities at ANU's advantaged status. The only way to offset such criticism was a demonstrable output of first-rate research; yet there were people with no undergraduate teaching responsibilities, generous provisions for study leave and ample time at their disposal who were not playing the game. There was too much 'frittering, pottering and gadding', in Hancock's view, ${ }^{61}$ and he was wont to hold forth about unproductive colleagues. Davidson referred to these sessions as 'Hancock's Half-Hour', after the long-running British television series. A frostiness developed between the two and a $\mathrm{PhD}$ student at the time recalls that Hancock 'oozed a patronizing disdain' for Davidson. ${ }^{62}$ The days of mutual regard between 'this admirable young man' and the 'brilliant colonial historian' were over.

Hancock was spoiling for a fight and made a point of exerting dominance and putting Davidson down. Soon after arriving, Hancock arbitrarily terminated the linkages between the Research School of Social Sciences (of which he was Director) and the Research School of Pacific Studies (with Davidson as Dean). ${ }^{63}$ He then muscled in on Indian history, insisting that the subject be developed in his own Department of History despite Davidson having laid a prior claim in his inaugural lecture. ${ }^{64}$ And Davidson suffered further defeat, indeed humiliation, when Hancock ruthlessly prevailed over the design of the Coombs Building, which to this day jointly houses the two social science research schools at ANU. ${ }^{65}$ Their different personal styles, previously of little moment, fuelled the acrimony. In William Roger Louis's words,

Hancock was a complicated and driven man. In my own view - I knew him from the mid-1960s onwards - there were two Hancocks. One was the intimidating public personage of strong opinions, pompous formality and impeccable courtesy. 'Professor Sir Keith Hancock', as he would introduce himself, insisted on wearing academic gowns at 
formal dinners at University House in Canberra. The other side of his personality was the private Hancock who was candid, open-minded and friendly though intellectually exacting. A pussy-footer he certainly was not. To those admitted to his circle of friendship, he was affectionate, steady and loyal. ${ }^{66}$

Those who knew Davidson - as I did in his last years - reveal a contrasting personality. He insisted on being called 'Jim' and was, as a colleague fondly recalled, 'in his private life a bit of a tearaway'. ${ }^{67}$ Like Hancock, there were two Davidsons. On the private side he was the most compassionate of friends and yet, despite his gregarious nature, essentially shy. The other side of the coin was the senior enfant terrible, whose casual attire (and disregard for the University House dress code), reckless driving, pronounced informality and unabashed irreverence starkly contrasted with his former sponsor's sensibilities. He was 'such a scallywag', said a colleague's wife rather admiringly, and not so approvingly a colleague described him as 'a charming man but a mischief-maker'. ${ }^{68}$ 'He wore his failings on his sleeve and was seldom averse to trailing his coat', remarked his colleague and close friend Oskar Spate (1911-2000), 'but in matters of delicacy, academic or human, his counsel was discreet, wise and humane'. ${ }^{69}$ Davidson's former student Alan Ward was another to sing his praises: 'His work, albeit limited on the publications side, was always serious, intense and highly professional ... . Any complete assessment of Jim . . . must include his enormous ability as a supervisor of graduate students.' Indeed, the published version of Ward's thesis on nineteenth-century race relations in New Zealand was reprinted on three occasions before going into a second edition and hailed by Eddie Durie, former chairman of the Waitangi Tribunal (and now Justice), as mediating future race relations in New Zealand. Contributing to this success and impact, says Ward, were the qualities that Davidson brought to his supervision: "the recognition of a penetrating topic and his sense of the dynamics of Polynesia/settler relations generally'; the ability 'to encourage the work by stimulating questions and discussions but otherwise to leave alone'; and meticulous readings of chapter drafts. 'What I also found encouraging', said Ward, 'was that he could lock horns with me in public (as we did over Sir George Grey in my first work-in-progress seminar) but graciously concede the point if I stuck to it and had good grounds for doing so. This was enormously confidence building. ${ }^{70}$ Davidson's critics, as Ward implies, did not seem to grasp his personal impact - the capacity to uplift and encourage in ways that transcend printed output, and which demonstrate the extent to which institution-building, scholarly opportunity and the structures of academic life generally are based on intangibles of the sort that Davidson could deliver. 
Davidson would certainly have done better on that score than Vincent Harlow, who beat him to the Beit chair at Oxford in 1948. Harlow continued to live in London and seldom came to Oxford more than once a week, preferring to work on what became The Founding of the Second British Empire. ${ }^{71}$ Harlow's Second Empire is perhaps the most significant revision of British imperial history in its broad sweep. It is a moot point, however, whether great works should come at the price of such neglect of institutional duties. And Hancock gives an almost frightening account of the 'absorption' and self-possession that drove him to complete his Survey of British Commonwealth Affairs whilst other duties, both professional and domestic, went into abeyance. In answer to his own question about whether he regretted his 'fanaticism', Hancock responded, 'Well, I finished the book ....? ${ }^{72}$

Davidson had loyal friends, and for good reason. But many colleagues were disconcerted, regarding his 'style' as undignified. A particular detractor was Mark Oliphant (1901-2000), who admitted that Davidson was not 'a favour of mine': 'He was a strange man in some ways .... He was appointed very young and he died too young, unfortunately, or he may have grown out of his youthful indiscretions. But he was the owner of a very fast motor car and always boasting about the time he could chop off his driving time to Sydney and so on, rather than a man of real academic interest. ${ }^{73}$ Hancock also came to the view that Davidson lacked seriousness of purpose. He and Davidson had commonalities in academic outlook, which initially brought them together; Davidson was always respectful, to the extent that he wore a tie whenever he met with Hancock. Equally, their contrasting personalities deepened the divisions once they clashed.

It did not stop there. Hancock viewed askance Davidson's increasing involvement in Western Samoa's lead-up to independence in the late 1950s and early 1960s. In fact, Davidson had considerable difficulty taking up the appointment as Constitutional Adviser, having to get around an obstructive Vice-Chancellor who objected to his lack of published output. ${ }^{74}$ The paradox is that had Davidson been prevented from being involved in the decolonization of Western Samoa, an important dimension would have been missing from his eventual book. A goodly proportion of Samoa mo Samoa was informed by Davidson's direct involvement in the affairs of those islands, beginning with the happy accident of fortune in 1947 when the New Zealand prime minister, Peter Fraser, despatched him to report on the political situation and prospects for self-government. The New Zealand government needed expert outside advice and it just so happened that Davidson was visiting Wellington at that very time. ${ }^{75}$ In keeping with his philosophy of history, Davidson not only wrote history but he also helped to 'make history'. It 
did not stop there: his 'greatest contribution' to academic study of Pacific Islands history was to champion the notion of the 'participant historian' - namely, that experience of life generally and a previous involvement with one's subject matter specifically were part and parcel of a historian's resources, and complemented 'adequate formal training' ${ }^{76}$

It is not that Hancock disputed that an interest in the past could legitimately derive from an absorption in the present, and neither did he eschew 'the complementary roles of professional historian and active citizen' any more that he necessarily disparaged the role of participant historian. ${ }^{77} \mathrm{In}$ 1954, after all, the British government engaged him as an independent expert to resolve the crisis in Buganda (a Kingdom within the British Protectorate of Uganda), and in his retirement Hancock was a conservation activist and prominent in the unsuccessful campaign to prevent a telecommunications tower being erected on Black Mountain in Canberra. ${ }^{78}$ Rather, Davidson's commitments as constitutional adviser in Western Samoa were seen as an inopportune distraction, and yet another impediment to his scholarly output at the very time it was found wanting. Davidson had not paid his dues. That was the difference between Hancock and Davidson in this regard. Hancock's involvement in the Buganda crisis was a public duty by someone who had earned his keep on the publishing front, while his involvement in the Black Mountain campaign took place in retirement when he was at liberty to fritter, potter and gad if he so chose.

It should not be thought that Davidson considered himself a failure and neither should he be regarded in that light, although the lost opportunities of the 1950s are undeniable. His contribution to the wider purpose of ANU is evident in his involvement in university governance, his supervision of students, his creation of a school of Pacific history and the editorship of the Journal of Pacific History. But Davidson was not an academic pur et simple. Rather, he assumed the mantle of participant historian and readily embraced the complementary roles of man of letters and man of affairs. There is no doubt that he regarded his continuing role in the decolonization of Oceania as the more important. He actively sought further assignments after Western Samoa and these had an effect on his published output. Under considerable compulsion, he wrote Samoa mo Samoa and did not complete another big book. A colleague who saw it at first hand remarked that he was 'bothered about Davidson because ... it didn't seem to me that he'd ever achieve anything ... it was the extreme difficulty of getting anything out of him in the research way'.79 This is to exaggerate, but not unduly. After all, Davidson was unable to complete his biography of Dillon and one reason was the frequency of absences from Canberra in the greater cause of decolonization. This is graphically brought out in the letter to a friend: 
Last weekend I was tempted to drop in on you in Auckland. I had been to Hong Kong . . ., Saipan, Ponape, and Honolulu. I could have got a plane via Auckland but decided against it as I have to go to New Guinea (for [a conference]) next Sunday, then in September to Fiji. I was in Micronesia earlier - in May - and may have to go again before the end of the year, so time in Canberra is precious - and insufficient for the writing I want to get on with. I am thinking of taking several months study leave in N.Z. early next year, in the hope of finishing Dillon. But I shall tell you about this and other things when I see you. ${ }^{80}$

\section{Finale}

Hancock was a compulsive writer in ways that Davidson was not. ${ }^{81}$ That was the root cause of their ruptured relationship, although the prolific Firth never lost his regard for Davidson. Notwithstanding their different personalities, Hancock and Davidson's philosophies of history were broadly in accord, especially the notion that an interest in the past could legitimately derive from an absorption in the present and, conversely, that engagement in the present informed the study of the past; and when Hancock first thought of accepting a position at the nascent ANU in the late 1940s, he expressed concern that its academics might isolate themselves from mainstreams of Australian affairs. ${ }^{82}$ Indeed, it has been stated that Hancock's very first publication on the question of the Low Countries 'indicated that historical appreciation of past events [in this instance a European topic dealing with the late eighteenth century] could be quickened by the writer's active participation in contemporary issues, ${ }^{83} \mathrm{He}$ and Davidson shared the belief that 'historians needed not more documents but stronger boots' (à la Tawney), and that 'a lust for life' would not go amiss. ${ }^{84}$ As well, they were on common ground methodologically, notably in their adherence to the notion of 'span'. While J.D.B. Miller speaks of Hancock's ability in 'combining exciting sweeps into general Commonwealth history with exact, particular studies of problems within the Commonwealth, joining the two by means of broad statements about the Commonwealth as a whole', William Roger Louis notes that Davidson 'attempted to shift the focus from Europeans to Islanders and, rather like Hancock, used the method of the case study to achieve his aim [with Samoa] ${ }^{85}$ Little wonder, then, that Hancock was delighted when Davidson produced Samoa mo Samoa, on the emergence of the modern Samoan state. He was pleased with both the fact of the book and the way Davidson had gone about it: 'She's a beaut', he wrote enthusiastically to Davidson. 'Your adorable Samoans come to life as individuals in an intricate and interesting society. Their story is worth telling in detail for its own sake and is also in some of its aspects microcosmic' ${ }^{86}$ It was again a 
case of concealed autobiography, with Hancock approving how successfully Davidson had accomplished a quality so evident in his own Survey of British Commonwealth Affairs. Instead of ranging far and wide in his research, Hancock had put down 'shafts' of enquiry in order to 'get to the roots of some specific problems in some specific territories', and then demonstrated their relationships with one another in order to avoid producing 'a disjointed aggregate of studies' within a single work.$^{87}$ Davidson did something not dissimilar in Samoa mo Samoa.

Fences were mended after a fashion, but the damage had been done. There was little warmth and Davidson is a notable omission among the contributors to Hancock's Festschrift. ${ }^{88}$ Not that it mattered so much because Hancock had retired as Professor of History in 1965. He stayed on as ANU's inaugural University Fellow and wrote his ground-breaking environmental history Discovering Monaro (1972). ${ }^{89}$ Although still a presence, he no longer occupied the corridors of power but mellowed and was more a father figure. ${ }^{90}$ Davidson, by contrast, became more acerbic toward the university administration, and senior colleagues sometimes felt his caustic wit. But his kindliness towards friends was undiminished and his supportiveness of younger scholars is legend. He continued to exercise a patronage that Hancock no longer had, choosing staff and postgraduate students, supporting or not supporting people in their quest for jobs or preferment, having a considerable say in what got published and what fell by the wayside, and in writing favourable or unfavourable book reviews. Davidson died suddenly in 1973, only 57 years old. He was outlived by almost all his associates from his own generation, and many from the generation before (Hancock, who was 17 years older, lived another 15 years). Neither had Davidson published as much as he could have, and this retarded the progress of Pacific history as a specialization during the $1950 \mathrm{~s} .{ }^{91}$ But his institutional work came to fruition in the 1960s and beyond with an impressive array of publications from staff and students. ${ }^{92}$ Those were the glory days of Pacific Islands historiography - that land of lost content that cannot come again (Housman).

The mentoring and enabling side of Davidson's work is often overlooked. Although he disparaged the notion of a 'Davidson School of Pacific Islands History', nevertheless he had an extraordinary knack for matching individual to a thesis topic, and through patronage and direction he shaped the course of the sub-discipline. This was still the age of the God-Professor and Davidson embraced the role, though not as a martinet. He was not the tyrant that some of his professorial colleagues could be and often were. Nonetheless, he was firmly in control, dispensing resources and patronage according to his own judgement of quality. He had the final say in the appointment of staff members and he set the salary levels of incoming staff. He not only 
hand-picked students but also decided by whom they would be supervised. He exercised an equally firm control over the departmental budget. He had definite ideas of what, and who, he did and did not want. ANU's Department of Pacific History was very much 'Davidson's Department' and there was no doubt that he ran the show, albeit with a certain patrician benevolence. Believing as he did in curiosity-driven research, Davidson encouraged people to follow their interests, knowing that really creative work springs from the heart. A colleague was to later remark that 'the thing that was good about Davidson's direction was the lack of it. He quite simply believed that people would do better research if they studied what interested them, rather than what appealed to him, or the powers-that-be, or the general public . . $[\mathrm{H}] \mathrm{e}$ was always supportive and intensely loyal should there be interference or ignorant criticism from outside'. ${ }^{93}$ In these ways, Davidson shaped his department and the sub-discipline of Pacific Islands history generally for the good, although it will always be argued that he might have done some things differently. That lively, charismatic figure bestrode his niche in the academic world and the fruits of his patronage are set in stone: from the mid-1960s, he presided over a glorious flowering of published endeavour - both his own and others - that put his distinctive brand of Pacific history onto a sound footing. And his participant work as constitutional advisor in the decolonization of Oceania, which is where his heart really lay, helped to shape the contemporary Pacific. ${ }^{94}$

1 Louis, William Roger, 'Introduction', in Robin W. Winks, ed., The Oxford History of the British Empire: Vol. Five, Historiography, Oxford, 1999, p.30. See generally W. David McIntyre, 'Clio and Britannia's Lost Dream: Historians and the British Commonwealth of Nations in the First Part of the 20th Century', Round Table, 93, 376 (2004), pp.517-32.

2 D.A. Low, ed., Keith Hancock: The Legacies of an Historian, Melbourne, 2001, p.11 (a listing a Hancock's books is provided on pages xiv-xvi of this volume). See also Anthony Low, 'William Keith Hancock, 1898-1988', Proceedings of the British Academy, 82 (1993), pp.399-414.

3 J.W. Davidson, Samoa mo Samoa: The Emergence of the Independent State of Western Samoa, Melbourne, 1967.

4 J.W. Davidson, The Study of Pacific History: An Inaugural Lecture Delivered in Canberra on 25 November 1954, Canberra, 1955; idem 'Problems of Pacific History', Journal of Pacific History, 1 (1966), pp.6-21; John M.R. Smail, 'On the Possibility of an Autonomous History of Modern Southeast Asia', Journal of Southeast Asian History, 2, 2 (1961), pp.72-102; Francis West, 'The Study of Colonial History', Journal of Southeast Asian History, 2, 3 (1961), pp.70-82; J.D. Fage, 'British African Studies Since the Second World War', African Affairs, 88 (1989), pp.397-413.

5 Donald Denoon and others, eds, The Cambridge History of the Pacific Islanders, Cambridge, 1997, pp.20, 25. 


\section{Journal of New Zealand Studies}

6 Winks (ed.), The Oxford History of the British Empire: Vol. Five, pp.30, 370-2; Ronald Hyam, 'The Study of Imperial and Commonwealth History at Cambridge, 1881-1981: Founding Fathers and Pioneer Research Students,' Journal of Imperial and Commonwealth History, 29, 3 (2001), pp.81-84, 98-99.

7 F.L.W. Wood (1903-89) [copy of reference on behalf of JWD], 11 April 1938, Davidson Papers, National Library of Australia, MS 5105, Box 61.

8 J.C. Beaglehole (1901-71) [copy of undated reference on behalf of JWD], Davidson Papers, NLA, MS 5105, Box 61.

9 'Degree Results, 1937: Honours etc.', Archives of the Department of History, Victoria University College, held in the J.C. Beaglehole Room, Victoria University Library, uncatalogued.

10 Davidson to D.G. Lilburn, 23 March 1938, Lilburn Papers, Wellington, Alexander Turnbull Library, MS-Papers-2483-052. Phillips (1916-2002) became Professor of History and Political Science, and later Vice-Chancellor, University of Canterbury.

11 J.W. Davidson, 'European Penetration in the South Pacific, 1779-1842', PhD thesis, Cambridge University, 1942.

12 E.A. Benians (1880-1952), Master of St John's College, Cambridge; A.P. Newton (1873-1942), Rhodes Professor of Imperial History, University of London. See Margaret Marion Spector, 'A.P. Newton', in Herman Ausubel, J. Barrett Brebner and Erling M. Hunt, eds, Some Modern Historians of Britain, New York, 1951, pp.286-305.

13 A.E. Benians, 'The Western Pacific, 1788-1885,' in J. Holland Rose et al., eds, The Cambridge History of the British Empire: Vol. Seven, Part One: Australia, Cambridge, 1933, pp.325-62; John M. Ward, 'The British Territories in the Pacific', in Robin W. Winks (ed.), The Historiography of the British Empire-Commonwealth: Trends, Interpretations, and Resources, Durham, NC, 1966, p.199.

14 Newton and Benians' examiners' reports are in the Cambridge University Library, UA BOGS 1 1942-43 Davidson.

15 E.A. Walker (1886-1976), Vere Harmsworth Professor of Naval and Imperial History, Cambridge University. Walker's patronage is outlined in Doug Munro, 'Becoming an Expatriate: J.W. Davidson and the Brain Drain', Journal of New Zealand Studies, 2-3 (2003-04), pp.26, 29, 31.

16 Davidson to his mother, 25 November 1940, 4 March 1941, Davidson Papers, NLA, MS 5105, Box 64. See also Michael W. Young, 'Raymond William Firth, 1901-2002', Journal of Pacific History, 38, 2 (2003), pp.277-80.

17 On historians' wartime experiences, see Jeremy Popkin, History, Historians and Autobiography, Chicago/London, 2005, pp.187-204.

18 J.W. Davidson, The Northern Rhodesian Legislative Council (London, 1948) was favourably reviewed, for example, by J.D. Fage, Cambridge Journal, 1, 11 (1948), pp.707-08. See also Patricia Pugh, 'Margery Freda Perham, 1895-1982', Proceedings of the British Academy, 111 (2001), pp.617-33.

19 Naval Intelligence Division [of the British Admiralty]. Pacific Islands (Geographical Handbook Series), 4 vols ([No place of publication], 1943-45); Hugh Clout and Cyril Gosme, 'The Naval Intelligence Handbooks: A Monument to Geographical Writing', Progress in Human Geography, 27, 2 (2003), pp.153-73.

20 Both reports are housed in the Archives of St John's College, Cambridge, D93.69.

21 Davidson, 'European Penetration', p.410, n.29.

22 A.L. Rowse, Historians I Have Known, London, 1995, p.23. 
23 Davidson to his mother, 8 June 1942, Davidson Papers, Box 65. Clark was later described as having a 'noncontroversial, "committee" approach to history'. Ved Mehta, Fly and the Fly-Bottle: Encounters with British Intellectuals, 2nd ed., New York, 1983, p.248.

24 Davidson submitted a revized version that won the Walter Lord Frewen Prize of the Royal Colonial Society for 1938. See Davidson to his mother, 7 November 1938, and 24 January 1943, Davidson Papers, NLS, MS 5105, Boxes 64 and 65 respectively. I have not been able to locate either copy of the revized version.

25 The adjudicator of the Royal Colonial Society's Walter Frewen Lord Prize for 1938 was also impressed by Davidson's 'personal knowledge of the people and the places concerned, a knowledge which he has used with good taste and a sense of proportion to give life to official facts'. J.A. Williamson, 'Report on the Essays Submitted for the Walter Frewen Lord Prize, 1938', encl. in the Minutes of the Imperial Studies Committee, Royal Empire Society (Cambridge University Library). Clark, by contrast, thought that Davidson had 'been at once diligent in seeking out materials and successful in constructing a consistent and intelligible narrative from them; but his general reflections do not rise above the commonplace'.

26 Denis Mack Smith, 'Hancock and the Risorgimento', in Low, Legacy, pp.15-21; David Cannadine, G.M. Trevelyan: A Life in History, London, 1993, pp.66-71, 148-9; W.K. Hancock, Country and Calling, London, 1954, pp.86-95.

27 W.K. Hancock, Survey of British Commonwealth Affairs, Vol. Two: Problems of Economic Policy, 1918-1939, Part 2, London, 1942, p.330. For a rather different appraisal, see John E. Flint, 'Mary Kingsley: A Reassessment', Journal of Africa History, 4, 1 (1963), pp.95-104.

28 For example, William Pember Reeves, The Long White Cloud [1898], Golden Press edition, 1973, p.189; James Hight and H.D. Bamford, The Constitutional History and Law of New Zealand, Christchurch, 1914, p.81; J.S. Marais, The Colonisation of New Zealand, Oxford, 1927, p.97.

29 Davidson, 'European Penetration', p.215.

30 C.R. Fay, 'The Movement Towards Free Trade, 1820-1853', in J. Holland Rose, A.P. Newton and E.A. Benians, eds, The Cambridge History of British Empire, Vol. Two: The Growth of the New Empire, London, 1940, p.399.

31 W.P. Morrell, New Zealand, London, 1935, pp.3-16 (ch.1: 'The Establishment of British Sovereignty'). Morrell (1899-1986) went on to become Professor of History at the University of Otago and wrote Britain in the Pacific Islands, Oxford, 1960.

32 Quoted in Davidson to his mother, 13 July 1942, Davidson Papers, NLA, MS 5105, Box 65.

33 Davidson to his sister, 4 February 1939; Davidson to his mother, 15 February 1939, Davidson Papers, NLA, MS 5105, Box 64; Davidson to Miles Greenwood, 3 November 1940, Greenwood Papers, NLA, MS 9805. Many of the more precious holdings of the Mitchell Library in Sydney were likewise dispersed to remote locations to minimize the risk of being bombed out. Sylvia Martin, Ida Leeson: A Life, Sydney 2006, pp.136-8.

34 Until the proliferation of area journals in the 1960s, the Economic History Review was the yardstick against which historians of empire measured their work. Louis, 'Introduction', p.35.

35 Hyam, 'The Study of Imperial and Commonwealth History at Cambridge', p.93, n.31.

36 J.H. Davidson, personal communication, 22 December 2005; Hancock, Country and Calling, p.189. See also Siân Nicholas, “Brushing Up Your Empire”: Dominion and Colonial Propaganda on the BBC Home Services, 1939-45', in Carl Bridge and Kent 


\section{Journal of New Zealand Studies}

Fedorowich, eds, The British World: Diaspora, Culture and Identity, London, 2003, pp.207-30.

37 Davidson to his mother, 2 August 1943, Davidson Papers, NLA, MS 5105, Box 65.

38 Jose Harris, 'Thucydides Among the Mandarins: Hancock and the World War II Civil Histories', in Low, Legacies, pp.122-48. The remainder of the paragraph is based on Davidson's letters to his mother between June and October 1944, Davidson Papers, NLA, MS 5105, Box 65.

39 'Extract of letter from Professor Firth dated 6/7/49' [should be 1948], Davidson's Personal File, ANU Central Records, 6.2.1.3(c).

40 Firth to Vice-Chancellor (Douglas Copland), 6 July 1948, London School of Economics Archives, Firth Papers, 4/48 (I owe the references from this source to J.H. Davidson).

41 The position went to the older and more experienced Vincent Harlow (1898-1961), who was A.P. Newton's successor as Rhodes Professor of Imperial History at London. Davidson to his mother, 23 May 1948, Davidson Papers, NLA, MS 5105, Box 65.

42 Davidson to his mother, 6 July 1948, 11 February 1949, Davidson Papers, NLA, MS 5105, Box 65; S.G. Foster and Margaret M. Varghese, The Making of the Australian National University, 1946-1996, Sydney, 1996, p.52.

43 Hancock to Vice-Chancellor (Douglas Copland), 21 March 1949 (copy; emphasis in original), London School of Economics Archives, Firth Papers, 4/48. Davidson reported to his mother, the previous month, that Hancock 'wants to have a long discussion with me before I go [back to Samoa] (amongst them the Australian National University, which he is likely to go to in a year or two)'. Davidson to his mother, 11 February 1949, Davidson Papers, NLA, MS 5105, Box 65.

44 Foster and Varghese, Making, p.45.

45 Hancock, Country and Calling, pp.235-45. For correction, see Foster and Varghese, Making, pp.43-50.

46 Davidson to his mother, 6 July 1948, NLA, MS 5105, Box 65; Foster and Varghese, Making, p.60.

47 Francis West, personal communication, 29 October 2000 (West was another departmental colleague at the time).

48 Clark, by contrast, saw nothing amiss in this feature of Davidson's work because he himself 'was never an archive-based historian, preferring to read widely in printed works and then ruminate'. Geoffrey Parker, 'George Norman Clark, 1890-1979', Proceedings of the British Academy, 66 (1980), pp.409-10, 421.

49 J.W. Davidson, 'New Zealand, 1820-1870: An Essay in Reinterpretation', Historical Studies, Australia and New Zealand, 5, 20 (1953), pp.349-60. This single journal article had a startling turn-around effect on New Zealand historiography. See Keith Sinclair, 'New Zealand', in Winks, The Historiography of the British Empire-Commonwealth, pp.175-7.

50 J.W. Davidson, Peter Dillon of Vanikoro: Chevalier of the South Seas (ed. O.H.K. Spate), Melbourne, 1975.

51 The basis for the intended short history was his extensive historical chapters in the Admiralty Handbooks, which remained classified. Davidson had obtained permission to use this material providing he did not disclose its provenance. Chief of Naval Information to Davidson, 30 August 1948, Davidson Papers, NLA, MS 5105, Box 1.

52 Tim Beaglehole, A Life of J.C. Beaglehole: New Zealand Scholar, Wellington, 2006, pp.410-11. 
53 The typescript of the collected essays, entitled 'Papers on Colonial Government', is in the Davidson Papers, NLA, MS 5105, Box 57. There is a reasonably complete listing of Davidson's publications by Norah Forster, 'Bibliography - J.W. Davidson', Journal of Pacific History, 28, 2 (1993), pp.278-81, which is supplemented by R. Gerard Ward, 'Davidson's Contribution to the "Admiralty Handbooks", Journal of Pacific History, 29, 2 (1994), pp.238-40. Davidson authored or co-authored some 600 pages in the various Admiralty Handbooks relating to the Pacific Islands.

54 Davidson to his mother, 24 June 1956, Davidson Papers, NLA, MS 5105, Box 66.

55 James Spillius, personal communication, 30 January 2006 (Spillius was a PhD student in anthropology at ANU during the early 1950s).

56 Robert Dare, 'First Discussion Session', in Stuart Macintyre and Peter McPhee, eds, Max Crawford's School of History, Melbourne, 2000, p.54.

57 Foster and Varghese, Making, pp.126-9.

58 Walter Crocker (1902-2002), interviewed by Stephen Foster, 9 August 1991, ANU Oral History Project, Interview No. 24, ANU Central Records (Crocker was foundation Professor of International Relations, ANU).

59 Popkin, History, Historians and Autobiography, p.160.

60 Keith Sinclair, Halfway Round the Harbour: An Autobiography, Auckland, 1993, p.133.

61 Ann Moyal, Breakfast with Beaverbrook: Memoirs of an Independent Woman, Sydney, 1995, p.124 (quotation); W.K. Hancock, Professing History, Sydney, 1976, p.23.

62 Ron Crocombe, personal communication, 25 February 2006 (Crocombe is Emeritus Professor of Pacific Studies, University of the South Pacific).

63 Hancock, Professing History, pp.37-38.

64 Hancock to Davidson, 10 July 1957, ANU Central Records, 6.1.1.7; Davidson, The Study of Pacific History, p.13.

65 Brij V. Lal, 'The Coombs: Journeys and Transformations', in Brij V. Lal, ed., The Coombs Building: A House of Memories, Canberra, 2006; Foster and Varghese, Making, pp.13334.

66 William Roger Louis, 'Sir Keith Hancock and the British Empire: The Pax Britannica and the Pax Americana,' English Historical Review, 120, 488 (2005), p.942.

67 Geoffrey Sawer (1910-96), interviewed by Dan Connell, 4 June 1990, ANU Oral History Project, Interview No. 06 (Sawer was foundation Professor of Law, ANU).

68 Telephone interview with Ruth Arndt, Canberra, 25 January 1999; Noel Butlin (1921-91), interviewed by Stephen Foster, 14 January 1991, ANU Oral History Project, Interview No.07 (Butlin was foundation Professor of Economic History, ANU).

69 O.H.K. Spate, ‘And Now There Will Be A Void: A Tribute to J.W. Davidson', Journal of Pacific Studies, 20 (1996), p.21 (Spate was foundation Professor of Geography, ANU).

70 Alan Ward (Emeritus Professor of History, University of Newcastle, NSW), personal communications, 6 and 9 August 1999; Alan Ward, A Show of Justice: Racial 'Amalgamation' in Nineteenth Century New Zealand, 2nd ed., Canberra and Toronto, 1974; Auckland, 1995.

71 Frederick Madden, 'The Commonwealth, Commonwealth History and Oxford, 1905-1971', in Frederick Madden and D.K. Fieldhouse, eds, Oxford and the Idea of Commonwealth, London/Canberra, 1982, p.19.

72 Hancock, Country and Calling, p.148.

73 Sir Mark Oliphant, interviewed by Dan Coward, 23 April 1990, ANU Oral History Project, Interview No.02 (Oliphant was Director of the Research School of Physical 


\section{Journal of New Zealand Studies}

Sciences, ANU, and later Governor of South Australia). The failures (and expense) of Oliphant's homopolar generator project at ANU might have given rise, after all these years, to some forbearance. Foster and Varghese, Making, pp.254-9.

74 Doug Munro, 'J.W. Davidson and Western Samoa: University Politics and the Travails of a Constitutional Advisor', Journal of Pacific History, 35, 3 (2000), pp.195-211.

75 Doug Munro, 'J.W. Davidson - The Making of a Participant Historian', in Brij V. Lal and Peter Hempenstall, eds, Pacific Lives, Pacific Places: Bursting Boundaries in Pacific History, Canberra, 2001, p.105.

76 Niel Gunson, 'An Introduction to Pacific History', in Brij V. Lal, ed., Pacific Islands History: Journeys and Transformations, Canberra, 1992, pp.4-5. Davidson's most extended statement is 'Understanding Pacific History: The Participant as Historian', in Peter Munz, ed., The Feel of Truth, Wellington, 1969, pp.25-46. For comparative purposes, see David Reynolds, In Command of History: Churchill Fighting and Writing the Second World War, London, 2004.

77 Foster and Varghese, Making, p.217 (quotation); Hancock, Country and Calling, esp. ch. 6 ('Exploring the Commonwealth').

78 D.A. Low, 'The Buganda Mission, 1954', Historical Studies, 13, 51 (1968), pp.353-80; Hancock, Professing History, pp.90-134; idem, The Battle of Black Mountain: An Episode in Canberra's Environmental History, Canberra, 1974.

79 John Passmore (1914-2002), interviewed by Stephen Foster, 17 May 1991, ANU Oral History Project, Interview No. 20 (Passmore was Professor of Social Philosophy at ANU).

80 Davidson to W.H. Pearson, 11 August 1970, Pearson Papers, Alexander Turnbull Library, MS-Papers-434-23.

81 Hancock recounts this compulsion, and his writing routines, in Country and Calling, pp.145-7, 209-11. He wrote the second volume of his biography of Smuts at ANU, and his institutional work included initiating the Australian Dictionary of Biography and organizing the multi-disciplinary 'Wool Seminar'. See Low, Legacies (chapters by Geoffrey Bolton, Libby Robin and Gerald Walsh); Alan Barnard (ed.), The Simple Fleece: Studies in the Australian Wool Industry, Melbourne, 1962; Moyal, Breakfast with Beaverbrook, pp.137-49.

82 Hancock, Country and Calling, pp.215-23; Foster and Varghese, Making, p.25.

83 Fred Alexander, 'Hancock: Some Reminiscences', Historical Studies, 13, 51 (1968), p.293; W.K. Hancock, 'Question of the Low Countries, 1792-1793', in M.D. Clark and Ronald Lowenstern, eds, Historical Studies by Students at the University of Melbourne, Melbourne, 1919, pp.66-75.

84 Hancock, Country and Calling, p.95; Low, 'Imperium et Liberatus and Hancock's Problems of Nationality', in Low, Legacies, p.59; Ross Terrill, R.H. Tawney and His Times: Socialism as Fellowship, Cambridge, MA, 1973, p.7.

85 J.D.B. Miller, 'Hancock, Mansergh and Commonwealth Studies', Historical Studies, 13, 51 (1968), p.396; Louis, 'Introduction', p.34. (Miller was Professor of International Relations, ANU.)

86 Hancock to Davidson, 26 July 1968, Davidson Papers, Noel Butlin Archives Centre, Canberra, Q25/19.

87 W.K. Hancock, Survey of British Commonwealth Affairs, Vol. One: Problems of Nationality, 1918-1936, London, 1938, p.ix; idem, Country and Calling, pp.164-5.

88 Essays Presented to Sir Keith Hancock, special issue of Historical Studies, 13, 51 (1968). 
89 See Trevor J. Daly, 'Discovering Hancock: A Profile of an Australian Environmental Historian (W.K. Hancock)', Limina, 4 (1998), pp.69-84.

90 But the embers were readily stoked. An interviewer in 1985 noted that, 'The person I found was very approachable and engaging. Beneath this amiable surface, however, lurked the old don, who could become impatient when he felt issues were being obscured or what was plain to him was not comprehended.' Neville Meaney, 'Reflections on Hancock's Australia', Australian Historical Association Bulletin, 43 (1985), p.10.

91 Even as late as 1964, only four monographs had been written by staff and former students of Davidson's Department. The students' publications were: Bernard Smith, European Vision and the South Pacific, 1768-1850: A Study of the History of Art and Ideas, Oxford, 1960; K.L. Gillion, Fiji's Indian Migrants: A History to the End of Indenture in 1920, Melbourne, 1962; R.G. Crocombe, Land Tenure in the Cook Islands, Melbourne, 1964. The one monograph from a staff member during that time was F.J. West, Political Advancement in the South Pacific: A Comparative Study of Colonial Practice in Fiji, Tahiti and American Samoa, Melbourne, 1961.

92 Many of these foundational texts are the subjects of chapters in Doug Munro and Brij V. Lal, eds, Texts and Contexts: Reflections in Pacific Islands Historiography, Honolulu, 2006. For a quite different appraisal, see Gavan Daws, 'Texts and Contexts: A FirstPerson View', Journal of Pacific History, 41, 2 (2006), pp.249-60.

93 Dorothy Shineberg, 'The Early Years of Pacific History', Journal of Pacific Studies, 20 (1996), p.10. Dorothy Shineberg, of cherished memory, was a Research Fellow, in the midto late-1960s, within 'Davidson's Department' before being moved into undergraduate teaching, which she did uncommonly well. Doug Munro, 'Wise, Humane and Sagacious: A Tribute to Dorothy Shineberg (1927-2004)', Journal of Pacific Studies, 27, 2 (2004), pp.277-81; Bronwen Douglas, 'Dorothy Shineberg: Pioneer Pacific Scholar, Inspiring Teacher, Friend', Journal of Pacific History, 40, 3 (2005), pp.353-6.

94 See J.W. Davidson, The Decolonisation of Oceania - A Survey, Wellington, 1971. 